\title{
LUT
}

University

\section{The effect of IC components on innovation performance in Serbian} companies

\author{
Cabrilo Sladjana, Kianto Aino, Misic Bojana
}

This is a Final draft

version of a publication

published by Emerald Publishing

in VINE Journal of Information and Knowledge Management Systems

DOI: $10.1108 /$ VJIKMS-06-2016-0033

Copyright of the original publication: @ Emerald Publishing 2018

Please cite the publication as follows:

Cabrilo, S., Kianto, A., Misic, B. (2018). The effect of IC components on innovation performance in Serbian companies. VINE Journal of Information and Knowledge Management Systems, vol. 48, no. 3. pp. 448-466. DOI: 10.1108/VJIKMS-06-2016-0033

This is a parallel published version of an original publication. This version can differ from the original published article. 


\title{
The Effect of IC Components on Innovation Performance in Serbian Companies $^{1}$
}

\begin{abstract}
Structured Abstract
Purpose - In researching the linkage between intellectual capital (IC) and innovation, it is important not only to explore how IC as a whole is associated with organization's innovative performance, but also to gain a deep understanding of the role of different IC components (groups of intangibles) in companies' innovation performance, which is the purpose of this paper in the context of Serbian companies.
\end{abstract}

Design/methodology/approach - This research is based on survey data collected from 100 Serbian companies with at least 100 employees during 2014/2015. Six IC components were analysed (human, structural, internal relational, external relational, renewal, entrepreneurial) in terms of their effect on innovation performance. Analyses were conducted with structural equation modelling (SEM) and correlation analysis.

Findings - Findings demonstrate that renewal capital, internal relational capital and structural capital have statistically significant positive effect on overall innovative performance in Serbian companies.

Practical implications - The outcomes reveal potential and barriers within IC, crucial to innovation performance in Serbian companies. In this way, this study enables deeper understanding of intangible drivers of innovation and highlights possibilities to foster intangible innovation potential in Serbian companies.

Originality/value -As context (economic and cultural) has emerged as a relevant factor in researching IC, this study is original in investigating IC effect on innovation within the Serbian business environment. Additionally, our broad sexpartite taxonomy of IC contributes to a wider understanding of knowledge and its linkages to innovation.

Keywords - Intellectual Capital, Innovation Performance, IC components, Serbia.

\footnotetext{
${ }^{1}$ An early version of this paper has been presented at the 10th International Forum on Knowledge Asset Dynamics (IFKAD), “Culture, Innovation and Entrepreneurship: connecting the knowledge dots", held in Bari (Italy), 10-12 June, 2015.
}

(c) Emerald Publishing Limited

This is a pre-print of a paper and is subject to change before publication. This pre-print is made available with the understanding that it will not be reproduced or stored in a retrieval system without the permission of Emerald Publishing Limited. 


\section{Paper Type Research Paper}

\section{Introduction}

Nowadays, an organization's value creation and competitiveness are largely based on intellectual capital (IC) (Bontis, 1998; Sveiby, 1997; World bank, 2005; Edvinsson and Malone, 1997; Stewart, 1997; Marr and Schiuma, 2001; Lerro et al., 2014; Inkinen, 2015) and organizational ability to innovate (Van de Ven, 1986; Cohen and Levinthal, 1990; Hamel, 1998). Therefore, intellectual capital and innovation, as well as the link between IC and innovation have gained more prominence among academics and practitioners.

Intellectual capital is a bundle of intangibles (Nahapiet and Ghoshal, 1998; Bontis, 1998; Sveiby, 1997) such as organizational knowledge, skills, experience, technology, and relationships that make a firm competitive at the market (Edvinsson and Malone, 1997). As it contains different types of intangibles, IC taxonomy have been largely discussed in the literature. Following the early conceptualization of IC in the late 1990s (Edvinsson and Malone, 1997; Sveiby, 1997; Bontis, 1998), a number of scholars generally consider three primary interrelated IC components: human capital, structural capital, and relational capital (Meritum, 2002; Marr, 2004). While three-dimension IC taxonomy has been established as an emergent standard (Inkinen, 2015), there is still some debate on what IC actually encompasses (Mention and Bontis, 2013). Additional IC components, such as renewal, entrepreneurial capital, social, and trust capital have surfaced in the academic literature (Kianto et al., 2014; Kianto, 2008; Erikson, 2002; Dost et al., 2016).

"Innovation is one of the most commonly mentioned concepts in social science" (Sveiby et al., 2009, p.2). Definitions of innovation, such as "any though, behavior or thing that is new because it is qualitatively different from existing forms" (Barnett, 1953, p.7), the commercial exploitation of good ideas that meet unmet need (Wolfe, 1994; Tidd and Bessant, 2009), and "putting ideas into action" (Cabrilo and Grubic-Nesic,2012, p.213), "creative application of knowledge in a new form" (Cavagnoli, 2011, p.111) already allude to the association of innovation with knowledge and IC. In the literature, most of the studies provide evidence for the tight link between IC and innovation performance of an organization (European Commission, 2006; Inkinen et al., 2014a, Lerro et al., 2014; Subramaniam and Youndt, 2005; Teece, 2007; Dumay et al., 2013). This link has been tested in many different contexts including regions such as Europe 
(Campanella et al., 2014), countries such as Finland (Inkinen et al., 2014a), Thailand (Mathuramaytha, 2012), and Japan (Takayuki, 2008, Sumita, 2008), specific industries such as ICT (Wang and Chingfu, 2005), and healthcare industries (Peng et al., 2007; Santos-Rodrigues et al., 2013), and specific types of enterprises such as social enterprises (Kong, 2010). Furthermore, some studies have examined the role of IC in producing different types of innovation, such as incremental and radical innovations (Subramaniam and Youndt, 2005; Darroch, 2005), or more precisely how categories of IC contribute to managers' perceptions on radical, evolutionary and incremental innovation (Dumay et al., 2013).

In order to provide insights into the factors promoting innovation, some studies have investigated the effect of particular intangibles or a selected component of IC on innovation performance. For example, while Cabello- Medina et al. (2011), Cabrilo et al. (2014), Wu et al. (2007), Marvel and Lumpkin (2007), and Alpkan et al. (2010) have investigated the linkage between human capital and innovation performance, DelgadoVerde et al. (2011) shed some light on the effect of structural capital on overall innovation performance.

The common finding seems to be that the IC dimensions are highly interrelated and increase the likelihood of firm's better innovation performance (e.g. Cabello-Medina et al., 2011; Leitner, 2011; Hsu and Sabherwal, 2012; Mathuramaytha, 2012). However, some studies have made a distance from a mainstream literature, criticizing the success bias associated with innovation (Sveiby et al., 2012), and questioning the contribution of all IC elements to different types of innovation performance (Dumay et al., 2013; Sveiby et al., 2009).

Therefore, this paper aimed to test and analyze how various components of IC affect innovation performance in Serbian business environment. The purpose is to develop an understanding of innovation performance and its association with different IC components in order to enable Serbian companies to link their innovation strategies with IC and promote a greater likelihood that innovation will be successful.

Serbia is a transitional economy undergoing privatization and reform of the public sector (Šabić et al., 2012; Veselinovic, 2014). In order to foster the development of knowledge and innovation driven economy, Serbia needs more findings related to these two drivers of economic growth and their interrelations. Unfortunately, there is limited empirical evidence on IC and innovation, as well as their linkage in Serbian context 
(Cabrilo, 2015). The first IC studies in Serbia were related to IC reporting, and were focused on a Serbian insurance company (Cabrilo, 2005), meso level and different industries, such as services (Cabrilo and Grubic-Nesic 2010), manufacturing (Kontic and Cabrilo 2009), public enterprises, mining and energy, banking, IT, and media (Cabrilo, 2015), comparison of reporting models in different industries (Cabrilo, 2009), and general IC reporting model for Serbian companies (Cabrilo et al., 2009). Related to the linkage between IC and performance in Serbian companies, authors have mainly explored the impact of IC on corporate performance (Bontis et al., 2013), and financial performance (Janosevic et al., 2013) by using Value Added Intellectual Coefficient (VAIC) method. These studies have been conducted in different Serbian industries such as banking (Bontis et al., 2013), hotel industry (Bontis et al., 2013a) and ICT sector (Dzenopoljac et al., 2016).

The paper contributes to the IC and management literature by expanding the wellknown three dimensional IC taxonomy, where IC is divided into human, relational and structural capital. In this paper, we consider also two additional IC components: renewal capital (Kianto et al., 2010) and entrepreneurial capital (Erikson, 2002; Firkin, 2003), and split relational capital into internal and external relational capital. Thus, this research enables more comprehensive understanding of how innovation performance is associated with different groups of intangibles. Furthermore, findings reveal that not all IC dimensions promote innovation performance, and provide insight into components that are not required and may even be harmful to innovation performance (Dumay et al., 2013). Finally, the study has been conducted in Serbian business context. While much of studies that explored the link between IC and organizational performance have focused on countries with large implementation of IC theory (Mention and Bontis, 2013; Andreeva and Garanina, 2016), little work so far has been done in transitional economies (Tovstiga and Tulugurova, 2007).

\section{Intellectual capital as a driver of innovation performance}

As interactions between types of IC in enabling innovation in the organization are socially complex and path dependent, they can be a source of sustained competitive advantage. This also means that it is difficult to discern the exact interrelationships between IC elements in creation of innovation. 
An innovation is basically a value-creating renewal of some sort, an implemented novelty that is useful for someone or something. Innovations range from new products and services, as process improvements, as developments in management and marketing methods, and as business model innovations.

The findings in previous studies that different types of innovation (be it of range or magnitude) are associated with different types of knowledge (e.g. Subramaniam and Youndt, 2005; Darroch, 2005), lead to assume that there could be differences in how various aspects of IC drive innovations. Therefore, in the following we provide a short rationale for each of the research hypotheses to be tested. We posit that each IC component (human, structural, internal relational, external relational, renewal, and entrepreneurial capitals) has a positive effect on innovation performance. IC can be, and typically is divided into more specific elements, covering the various "locations" of knowledge in organizations. We will discuss these elements and their impact on innovation performance in the following sections.

The vast majority of the past studies consider that IC consists of human capital, structural capital and relational capital. Thus, it has been seen to include human skills, expertise and motivation; the structural features of production embedded in organizational processes, systems, solutions, databases, patents and IPs; and the value embedded in the network of relationships. However, we suggest that a more thorough understanding of the knowledge-based antecedents of innovation can be achieved by including two novel types of IC, namely renewal and entrepreneurial capitals. Renewal capital refers to organizational ability to learn and update its knowledge base (e.g. Kianto, 2008; Kianto et al., 2010), while entrepreneurial capital refers to employees' ability to identify business opportunities, take risks and make difficult decisions (Erikson, 2002; Firkin, 2003). Since knowledge creation and learning (e.g. Nonaka \& Takeuchi, 1995) as well as proactiveness and risk taking (e.g. Lumpkin \& Dess, 1996) have been linked with innovation, we expect these two IC dimensions to provide additional explanation to the antecedents of innovation beyond the more traditional IC dimensions. Moreover, we decided to split relational capital into "internal" and "external" categories, because the two categories relate to relationships with different stakeholders. Traditionally, relational capital only refers to an organization's relationships with external parties, but in our model, we separate intra-organizational relationships. This broad 6-partite definition of IC is based upon a wide understanding of knowledge, as not only the explicit outcomes of 
knowledge-intensive work such as patents, formulae and actualized products, but also as the tacit potential of organizational actors to e.g. flexibly react to unexpected situations and rapidly changing customer demands. Thus it encompasses both the static and dynamic dimensions of intellectual capital (Kianto, 2007).

Human capital consists of the human skills, expertise, and motivation at work. The majority of the empirical literature provides interesting arguments about the key role of human capital for innovation activities, as the value and uniqueness of human knowledge are essential for innovation process (Lepak and Snell, 1999; Cabrilo et. al, 2014). Early studies reveal that some intangibles within HC positively affect innovation performance (Miller and Friesen, 1982; Zahra, 1996). However, in the last 15 years, there has been much more empirical evidence that organizational ability to innovate is inextricably linked to its human capital (Laursen, 2002; Anker, 2006; Cabello-Medina et al., 2011), as well as that $\mathrm{HC}$ has a positive effect on innovative performance (Wu et al., 2007; Marvel and Lumpkin, 2007; Alpkan et al., 2010).

Structural capital stands for an organization's structural features of production, embedded in organizational processes, systems, solutions, databases, patents and IPs, as well as softer issues such as organizational culture and climate of collaboration. These structures have enabled innovation through building the electronic, as well as mental infrastructure for knowledge creation and innovation. Databases enable collecting and reusing the explicit knowledge, and processes enable building collective knowledge of the firm. Not surprisingly, several previous studies have demonstrated structural capital to exert a positive influence on e.g. new product development (Aramburu and Saenz, 2011) and overall innovation performance (Delgado-Verde et al., 2011).

Relational capital is the value embedded in the network of relationships. While typically, IC models only address the external relationships of the firm as elements of relational capital (Edvinsson and Malone, 1997; Sveiby, 1997; Roos et al., 1998), we argue that also the intra-firm relationships should be addressed as a prime element of IC, distinctly from external relations. Therefore, in this research we have decided to split relational capital into "internal" and "external" categories, the two categories relating to relationships with different stakeholders. While both external and internal relationships have been associated with innovation, it also seems that there are differences in how they impact knowledge creation. For example, intra-firm relationships might be more beneficial for impacting renewals in terms of processes and management, while external 
relationships might bring more benefit to developing renewals that the customers like, in the form of product/service and marketing innovations.

Renewal capital represents the resources of the firm for renewing what it knows and can do. It consists of the ability of the firm to acquire new information, develop skills, and to learn. An organization with high renewal capital, sometimes also called innovation capital (Chen et al., 2004), is able to build on previous knowledge and to generate new knowledge (Maditinos et al., 2010), as well as to develop new products, services, and innovative ideas on a continuous basis (Tseng and Goo, 2005), and thus innovate. Edvinsson (2002) has even argued that as organizations have to survive in turbulently and unexpectedly changing environments, renewal capital has become the most important facet of IC.

Entrepreneurial capital consists of the competence and commitment related to entrepreneurial activities in the organization (e.g. Erikson, 2002). Despite different interpretations, it has been found that entrepreneurial capital impacts innovation (Hughes and Morgan, 2007), and entrepreneurial firms are more successful in innovation (Cohen and Levin, 1989; Scherer, 1999). Even at the societal level, it seems that entrepreneurship is essential to producing more innovation (Michael and Pearce, 2009). An organization with high entrepreneurial capital will be more innovative through having electronic and mental infrastructures that enable and support knowledge codification, collection, memorizing, socializing, and search, and thereby aid innovation.

Taking together the arguments presented in the previous section of the paper concerning the associations of IC elements and innovation, we posit the following set of hypotheses:

H1: Internal relational capital has a positive effect on overall Innovation performance.

H2: External relational capital has a positive effect on overall Innovation performance.

H3: Structural capital has a positive effect on overall Innovation performance.

H4: Human capital has a positive effect on overall Innovation performance.

H5: Renewal capital has a positive effect on overall Innovation performance.

H6: Entrepreneurial capital has a positive effect on overall Innovation performance.

\section{Research Method}

\subsection{Sample and data collection}


The study was carried out in Serbia during 2014/15 by means of a structured questionnaire. Online survey was created with Google Forms and posted on the Internet. The criteria for selecting companies were that a company has at least 100 employees. All companies in Serbia are divided into four groups (micro, small, medium, and large) by their number of employees, revenues and assets. According to the Statistical Office of the Republic of Serbia ${ }^{1}$, the total number of enterprises in Serbia in 2013 was 87,529. There were 2,011 medium enterprises (50-249 employees), and 489 large companies (more than 250 employees), whereas 85,029 companies were micro and small companies having less than 50 employees. Some database of the Chamber of Commerce and Industry of Serbia ${ }^{2}$ and Serbian Business Registers Agency ${ }^{3}$ were utilized in identifying eligible companies. Call for participation and the link to the online survey were electronically sent to 250 randomly selected companies. Finally, responses from 100 companies were included in the sample for further consideration.

To ensure the representativeness of the sample, we included diverse companies with regard to ownership structure, industry, and geographic location/region in the sample. Regional disparity in Serbia has been among the highest in Europe (Đorđević et al., 2014). During the transition to the market economy, this imbalance has increased as low developed districts did not have potential to catch up with leading regions in the country (Mijačić and Paunović, 2011). Disparity has been reflected by the factors like per capita income, population density, the proportion of population living below the poverty line, employment, unemployment, business demography, development of infrastructure, and level of education (Mijačić and Paunović, 2011; Đorđević et al., 2014). Level of regional development is one of the relevant factors for the performance of organizations in that region. Therefore, when analyzing the effects on organizational performance, regional diversity of the sample should be taken into consideration. Table I and Table II present the list of regions and industries included in the sample, respectively.

According to the nomenclature of statistical territorial units at level 2 (NUTS 2) of EU regional policies, with population between 800,000 and 3 million, and The Law on Regional Development of the Republic of Serbia (2010), territory of Serbia is divided in 5 regions: 1) Vojvodina; 2) Belgrade; 3) Šumadija and Western Serbia; 4) Southern and

\footnotetext{
${ }^{1}$ Statistical Yearbook of the Republic of Serbia 2015, http://webrzs.stat.gov.rs/WebSite/ repository/documents/00/01/88/53/Statisticki godisnjak Srbije 2015.pdf

${ }^{2}$ http://www.pks.rs/default.aspx?idjezik=3

${ }^{3} \mathrm{http}: / /$ www.apr.gov.rs/eng/Home.aspx
} 
Eastern Serbia; 5) Kosovo and Metohija. Serbia-North district is comprised of Belgrade and Vojvodina regions, and Serbia-South is comprised of three other regions.

Regional indicators show that Vojvodina and Belgrade are developed regions, regions of Šumadija and Western Serbia, and Southern and Eastern Serbia are medium-developed and Kosovo and Metohija is an underdeveloped region (Grujić et al., 2010). The concentration of companies (especially medium-sized and large companies), and economic activities lies in Serbia-North (Belgrade and Vojvodina regions), which has higher employment and a higher number of successful companies (Đorđević et al., 2014). Serbia-North dominates over Serbia-South in business demographics, and Beograd region dominates over three other regions (Statistical Yearbook of the Republic of Serbia, 2015). In $2013,70 \%$ of all companies in Serbia (87.529) were from Serbia-North, while $30 \%$ were from Serbia-South (Belgrade-44.8\%, Vojvodina-25.2\%, Šumadija and Western Serbia-18.4\%, Southern and Eastern Serbia-11.6\%). The regional disparity in number of enterprises has even increased in comparison to 2009 , when there were $56.7 \%$ companies registered in Serbia-North and $43.3 \%$ working in Serbia-South. According to all indicators, Serbia has been divided in developed Serbia-North, and a lagging behind Serbia-South (Mijačić and Paunović, 2011; Đorđević et al., 2014).

\section{TABLE I GOES HERE}

The number of surveyed companies varied across the regions. In addition to the concentration of companies and economic activities in north regions (Belgrade and Vojvodina), the willingness of companies has primarily determined regional composition of the sample. The most companies in the sample were from developed regions Belgrade (42\%) and Vojvodina (33\%). In other words, $75 \%$ of companies in the sample were from more developed Serbia-North, and much less (25\%) from less developed Serbia-South regions of Šumadija and Western Serbia (15\%), and Southern and Eastern Serbia (10\%). Having in mind the current relations between Serbia and Kosovo, invited companies from Kosovo didn't respond to the questionnaire and this region was not included in the sample.

\section{Table II GOES HERE}

Most companies in the sample (49\%) were manufacturing companies, followed by the companies from information and communication industry $(12 \%)$, administrative and support service industries $(8 \%)$, and financial and insurance services $(8 \%)$. 


\section{Table III GOES HERE}

Respondents mainly held the high managerial positions, so it was assumable that they were sufficiently familiar with organizational performance, which is important to ensure relevant responses.

\subsection{Measurement of variables}

Both intellectual capital components and innovation performance have been regarded as multidimensional constructs. All constructs are presented in Appendix A.

Dependent variables - In this study, five types of innovation performance were considered as dependent variables: performance for product/service innovation, process innovation, innovation of management practice, innovation of marketing practice, as well as business model innovation. All measures were developed by Weerawardena (2003). On a five-point Likert scale (1 - strongly disagree, 5- strongly agree), respondents rated organizational performance related to each type of innovation in comparison with other companies in their industries.

Independent variables - IC components were measured with Likert-type items (five point Likert scale; 1 - strongly disagree, 5- strongly agree), with the scales developed by Kianto, Inkinen, Vanhala and Ritala and presented earlier e.g. in Inkinen et al. (2014a; 2014b). There were two items were related to internal and two to external relational capital, four items to structural capital, two items to human capital, four items to renewal capital, and six items were related to entrepreneurial capital.

\section{Results}

\subsection{Correlation analysis}

The intensity and direction of the linear correlation between the variables covered by this study, as well as means and standard deviations, are presented in the table below (Table IV). Pearson's coefficient product-moment correlation coefficient was used as a measure of correlation between tested variables.

\section{Table IV GOES HERE}


As the correlation matrix shows, there are statistically significant positive correlations between different IC components and overall innovation performance. This indicates that high IC stocks are accompanied by high levels of innovation performance. Furthermore, positive correlations between six IC categories reveal interconnectedness between different IC components.

\subsection{Research model testing}

Structural equation modelling (SEM), by using Partial Least Squares path modelling, has further been used in order to test the research model of IC categories and different types of innovation performance, as well as the hypotheses.

Hair et al. (2013) suggest that using variance based SEM, such as PLS-SEM, requires sample size that could be determined by the largest number of formative indicators, and by the largest number of structural paths directed at particular construct. The number of observations should be at least 10 times larger than mentioned numbers. Since the largest number of formative indicators and directed structural paths are both 6 , the sample data from 100 observations can be tested with this method.

As stated by Bock et al. (2005), in order to test and evaluate the research model, internal consistency, as well as construct validity - convergent and discriminant validity must be assessed (see Table V and Table VI).

\section{Table V GOES HERE}

\section{Measurement model}

In order to test the internal consistency measurement models, we assessed the composite reliability (CR). As Fornell \& Larcel (1981) suggest, recommended value of $\mathrm{CR}$ is 0.70 or above. Under given results, CR for all constructs are 0.90 and above.

The evaluation of convergent validity was based on the evaluation of Average Variance Extracted (AVE) and factor loadings. Average Variance extracted is a number that shows how much of variance is explained by latent variables. In most research studies 0.5 was taken for AVE lower limit (adopted by: Fornell \& Larcker, 1981). AVE values in this research range from 0.67 to 0.84 . Factor loadings of the research model presented in the Appendix, are high and statistically significant (above 0.7, adopted by 
Chin et al. 2003).

\section{Table VI GOES HERE}

As presented in the Table VI, Fornell-Larcker Criterion was used in order to examine discriminant validity. Squared correlations of the latent variables are presented in the lower left part of the table, while diagonal values are replaced with AVE values. Fornell-Larcker Criterion demands that AVE of the latent variable must have greater value than all correlations with other latent variables. As presented in the table below, discriminant validity is reached, since all the AVE values are greater than the values of squared correlations in the column below.

Presented results are a satisfactory evidence of validity and reliability for constructs examined in this research.

\section{Table VII GOES HERE}

\section{Structural model}

In formative models, such as the one in this research, the problem of indicator collinearity may occur. To avoid collinearity problem, we need to have Variance Inflation Factor (VIF) of 5 or lower (Hair et al. 2011).

In order to achieve stabile estimates, it is necessary to check after how many iterations SmartPLS algorithm was stopped. The maximum number of iterations that was used is 300 , and algorithm was stopped after five iterations due to stop criterion.

We will start the evaluation of structural model by examining the coefficient of determination $\mathrm{R}^{2}$. Some authors state that $\mathrm{R}^{2}$ values of 0.5 and above are marked as significantly high. In given Innovation performance model, the value of the determination coefficient is 0.543 , meaning that more than half of variance is explained by latent variables.

Structural model represents the presumed connections between constructs. Path coefficients represent statistical indicators of direct effects between constructs in structural models. Hensler et al. (2009) state that path coefficients are analogous to standardized beta coefficients in multiple regression analysis, and are interpreted in the same manner. Since path coefficients with a negative sign do not confirm the 
assumptions, human capital does not affect overall innovation performance in this research model.

Statistical significance was examined with bootstrapping procedure. Based on the model test results, we can conclude that three out of six latent constructs have statistically significant path coefficients. Path coefficients are statistically significant for $\beta=0.312$ for Renewal capital $(\mathrm{p}<0.05), \beta=0.228(\mathrm{p}<0.05)$ for Internal relational capital, and $\beta=0.222$ for Structural capital $(\mathrm{p}<0.05)$. Hence, renewal capital is the best predictor of overall innovation performance, followed by internal relational capital and structural capital.

\section{Discussion}

We have analysed how different components of IC affect overall innovative performance in the particular context of Serbian business environment. We found that IC indeed impacts innovation. More specifically, we found some differences in how IC components contribute to innovation performance, and identified renewal capital, internal relationship capital, and structural capital to have significant predictive role in innovation performance of Serbian companies. Another important conclusion, which is in contrast with the majority of the existing IC literature, is that human capital does not affect overall innovation performance. Therefore, hypotheses H1, H3, and H5 (internal relationship, structural, and renewal capitals have statistically significant positive effect on overall innovative performance) are supported, while $\mathrm{H} 2, \mathrm{H} 4$, and $\mathrm{H} 6$ are rejected (external relational, human, and entrepreneurial capitals do not affect innovation performance) in Serbian business environment.

Trying to explain the most predictable role of renewal capital in innovation performance, it is relevant to take into consideration organizational learning literature. Learning is the only process for creating new knowledge (Weggeman, 1997), or building new knowledge assets (Argyris, 2002). Innovation is a new idea, thought or behavior, different from existing ones. Thus, it is not possible to innovate with already existing knowledge without the creation of new knowledge, i.e. learning (Cabrilo and Grubic Nesic, 2012). Therefore learning enhances organizations' innovativeness (Hurley and Hult, 1988), and effectiveness of knowledge creation process (learning) determines the level of innovation (Nonaka and Takeuchi, 1995). As renewal capital is "actualized learning capability of the firm" (Inkinen et al., 2014a; 2014b), it becomes obvious that effectiveness of learning and renewal capital significantly affects innovation process. 
Findings from Serbian business context that renewal capital has the most significant positive effect on innovation performance are in line with theoretical argumentations. However, data in Table IV reveals that renewal capital is the second least developed component of IC in Serbian companies (the second lowest mean and the highest standard deviation). That might be explained by the fact that companies in Serbia still do not have high renewal capital (as a stock), or high effective learning processes, but those companies that are able to focus learning processes on innovation making learning more effective, will significantly enhance overall innovation performance.

As hypothesized, internal relational capital has a positive and significant influence on Serbian firms' innovation performance. Having in mind that external relational capital does not affect innovation performance, it can be concluded that Serbian companies still mostly implement closed approach to innovation, integrating only core inside innovators in the innovation process. These findings are not in line with emerging approach of open innovation, in which innovation process involves different external stakeholders, such as suppliers, customers, universities, or competitors (Chesbrough, 2003; Maklan et al., 2008; Rass et al., 2013). By open approach to innovation companies use external relationships to benefit from a more diverse set of ideas and knowledge (Rass et al., 2013). According to the Table IV, external relational capital has a high mean and the lowest standard deviation in the sample. In other words, Serbian companies have intensive relations with external stakeholders (this IC component is relatively strong within Serbian companies), but they do not use efficiently external relational capital in innovation processes. The significant role of structural capital might be explained by large number of manufacturing companies in the sample. Some studies found that structural capital is the most influential IC component on performance in non-service companies (Andreeva and Garanina, 2016; Bontis et al., 2000).

While the result in this study, that human capital does not affect innovation seems to challenge mainstream IC and innovation literature, there has been more empirical evidence pointing to no significant direct links between human capital and different organizational performance (Bontis, 1998; Stewart, 1997; Cabrita and Bontis, 2008), or even negative influence of human capital on innovation performance (Inkinen et al., 2014a). For example, Inkinen et al. (2014a) examined similar IC components and their impact on the organizations' market and innovation performance in Finnish companies. They found that human capital had a negative influence on innovation performance

(c) Emerald Publishing Limited

This is a pre-print of a paper and is subject to change before publication. This pre-print is made available with the understanding that it will not be reproduced or stored in a retrieval system without the permission of Emerald Publishing Limited. 
explaining that, as a resource, human capital had to be efficiently and effectively managed to affect innovation process (Kianto, 2007). While Santos-Rodrigues et al. (2011) discovered that there have been no direct links between human capital and management innovativeness, human capital has been related to the incentives to innovation (SantosRodrigues et al., 2013) and product-process innovativeness (Santos-Rodrigues et al., 2011). Furthermore, Dumay et al. (2013) revealedthat different types of innovation (radical, incremental, and evolutionary) are driven by different combinations of IC components. In their study, human capital was found to be a key factor of successful incremental innovation.

However, all of these studies provide evidence of the interrelationships among IC components with positive influence on performance (Cabrita and Bontis, 2008; Dumay et al., 2013; Stewart, 1997), and emphasize a need to manage the interaction between all IC components in order to support successful innovation (Dumay et al., 2013). In the case of Serbian companies, results suggest that human capital needs the other IC components to be fully capitalized in innovation process. Finally, our findings that innovation processes have different supporting IC components, and that not all components are relevant nor positively contribute to successful innovation, are in line with some previous studies (Inkinen et al., 2014a; Dumay et al., 2013; Santos-Rodrigues et al., 2011).

\section{CONCLUSION}

By taking a holistic perspective across different IC components and their association with innovation performance, this study has provided evidence about the interconnectedness of all IC categories. Our study reveals that the assumption that all IC components are relevant, and have a positive effect on innovation performance, may not be valid in all cultural and business environments, as well as that overall innovation performance has various supporting IC components (Inkinen et al., 2014a; Dumay et al, 2013).

From an academic perspective, the contribution of this study is threefold. While most authors focus only on three well-known IC categories that might enhance innovation, this research considers a broader view of the diverse and interrelated IC dimensions. We expanded IC taxonomy with new dimensions - renewal capital (Kianto et al., 2010) and entrepreneurial capital (Erikson, 2002; Firkin, 2003), and by splitting relational capital into internal and external relational capital, we consequently got a more holistic 
understanding of how innovation is associated with different IC dimensions. By researching how different IC components affect innovation performance, this study has found that some of the IC components, that have generally been accepted to be necessary, and to have positive influence on innovation, were not always required, and may even be harmful to innovation performance. This result contributes to differentiation theories of innovation practice (Dumay et al., 2013). Finally, the study has been conducted in transitional Serbian business context. As the results challenge existing IC and innovation mainstream literature, we can conclude that studies from emerging markets or other transitional environments may advance existing IC theories (Andreeva and Garanina, 2016), and enable fine-tuning regarding the particular faces of the context.

From practical perspective, these findings contribute to better understanding of main drivers of innovation and competitiveness in Serbian business environment, and help managers to maximize innovation performance, not just by initiatives focused on the most influential IC stocks like renewal capital, internal relational capital and structural capital, but initiatives focused to expand the least developed components in IC.

Overall, the study contributes to the discussion in the knowledge-based approach by pointing out that IC matters for innovation, and that for understanding innovation performance, there might be more to IC than the traditional $\mathrm{HC}, \mathrm{SC}$ and $\mathrm{RC}$-division. Considering that the two novel IC components (renewal and internal relational capital) are the most influential for innovation in Serbian environment, expanding traditional IC taxonomy seems to be reasonable.

The main limitation of this paper is that results were based on subjective measures collected by the survey in the Serbian context. Therefore, future studies should include some objective performance measures as dependent variables. The second limitation is that data collection was done in organizations from one business and cultural context, so the results of this study should not be interpreted as universal, and applied to either research or practice in different national cultures or cultural clusters. The third limitation is related to the regional composition of the sample. Most companies in the sample were from two developed Serbian regions. The composition of the sample in this study leaves a space for doubt that findings represent business reality in all Serbian companies, especially from less developed regions. Finally, the result that human capital does not affect innovation performance needs to be explored and explained much more in depth, which may be a task of a future research. 


\section{References}

Lumpkin G T and Dess G G (1996) Clarifying the entrepreneurial orientation construct and linking it to performance. Academy of management Review, Vol. 21, No. 1, pp. 135-172.

Yang, C. and Lin, C. (2009), "Does intellectual capital mediate the relationship between HRM and organizational performance? Perspective of a healthcare industry in Taiwan". International Journal of Human Resource Management, Vol. 20, No. 9, pp. 1965-1984.

Alpkan, L., Bulut, C., Gunday, G., Ulusoy, G. and Kilic, K. (2010), "Organizational support for intrapreneurship and its interaction with human capital to enhance innovative performance", Management Decision, Vol. 48, No. 5, pp. 732-755.

Andreeva, T. and Garanina, T. (2016), "Do all elements of intellectual capital matter for organizational performance? Evidence from Russian context", Journal of Intellectual Capital, Vol.17, No. 2, pp.397-412.

Anker, L.V. (2006), "Absorptive capacity and innovative performance: a human capital approach", Economics of Innovation and New Technology, Vol. 15, No. 4-5, pp. 50717.

Aramburu, N and Sáenz, J. (2011), "Structural capital, innovation capability, and size effect: An empirical study", Journal of Management \& Organization, Vol. 17, No. 3 , pp.307-325.

Argyris, C. (2002), "Teaching Smart People How to Learn", Reflections, Vol. 4, No. 2, pp. $4-15$.

Bock, G., Zmud, R. W., Young-Gul, K., \& Jae-Nam, L. (2005). Behavioral intention formation in knowledge sharing: Examining the roles of extrinsic motivators, socialpsychological forces, and organizational climate. MIS Quarterly, 29 (1), 87-111.

Bontis, N. (1998), "Intellectual capital: an exploratory study that develops measures and models", Management Decision, Vol. 36, No. 2, pp. 63-76.

Bontis, N., Janosevic, S. and Dzenopoljac, V. (2013), "Intellectual capital and the corporate performance of Serbian banks", Actual Problems of Economics/Aktual'ni Problemi Ekonomiki 142 (4), pp. 287-299.

Bontis, N., Janosevic, S., Dzenopoljac, V. (2013a), "Intellectual capital in Serbia's hotel industry", International Journal of Contemporary Hospitality Management, Vol. 27, No. 6, pp. $1365-1384$.

Bontis, N., Keow, W.C.C. and Richardson, S. (2000), "Intellectual capital and business performance in Malaysian industries", Journal of intellectual capital, Vol. 1, No.1, pp.85-100.

Cabello-Medina, C., López-Cabrales, A. and Valle-Cabrera, R. (2011), "Leveraging the innovative performance of human capital through HRM and social capital in Spanish firms", The International Journal of Human Resource Management, Vol. 22, No. 4, pp. 807-828. 
Cabrilo, S. (2005), "The first IC reports in Serbia and Montenegro." INFO M, Vol 15-16, pp. 15-21.

Cabrilo, S. (2009), "IC-Based Inter-Industry Variety in Serbia", Electronic Journal of Knowledge Management (EJKM), Vol 7, Issue 4, pp. 425-436, July 2009.

Cabrilo, S. (2015), ,The Overview of IC Reporting Models within Serbian Industries”, in Ordoňez de Pablos, P. and Edvinsson, L. (Ed.), Intellectual Capital in Organizations: Non-Financial Reports and Accounts, Routledge, pp. 109-149.

Cabrilo, S. And Grubic Nesic, L. (2012), The Role of Creativity, Innovation and Invention in Knowledge Management, In Buckley, S. B. \& Jakovljevic, M. eds, Knowledge Management Innovations for Interdisciplinary Education: Organizational Applications, Hershey PA: IGI Global, pp. 207-233

Cabrilo, S. and Grubic-Nesic, L. (2010), „A Strategic model for intellectual capital reporting: Study of service industry in Serbia", in Proceedings of the $2^{\text {nd }}$ European Conference on Intellectual Capital, 29-30 March, ISCTE Lisbon University Institute, Lisbon, Portugal and Polytechnic Institute of Leiria, Lisbon, Portugal, pp. 161-171.

Cabrilo, S., Grubic Nesic, L. and Mitrovic, S. (2014), "Study on human capital gaps for effective innovation strategies in the knowledge era", Journal of Intellectual Capital, Vol. 15, Issue 3, pp. $411-429$.

Cabrilo, S., Uzelac Z. and Cosic I. (2009), "Researching indicators of organizational intellectual capital in Serbia", Journal of Intellectual Capital, Vol. 10, No. 4, pp. 573-587.

Cabrita, M. R. and Bontis, N. (2008), "Intellectual capital and business performance in the Portuguese banking industry", International Journal of Technology Management, Vol. 43, No. 1-3, pp. 212-237.

Campanella, F., Rosaria Della Peruta, M. and Del Guidice, M. (2014), "Creating indicators for innovative performance of science parks in Europe. How manage the intellectual capital for converting knowledge into organizational action", Journal of Intellectual Capital, Vol 15, No. 4, pp. 576-596.

Cavagnoli, D. (2011). A conceptual framework for innovation: An application to human resource management policies in Australia. Innovation: Management. Policy \& Practice, 13(1), 111-125.

Chen, J., Z. Zhu, and Xie, H. Y. , (2004) "Measuring intellectual capital: a new model and empirical study", Journal of Intellectual Capital, Vol. 5, No. 1, pp. 195-212.

Chesbrough, H.W. (2003), Open Innovation: The New Imperative for Creating and Profiting from Technology, Harvard Business School Press, Boston, MA.

Chin, W. W. (1998). The partial least squares approach for structural equation modeling. In G. A. Marcoulides (Ed.), Modern methods for business research (pp.295-336). Mahwah, NJ: Lawrence Erlbaum Associates Publishers.

Cohen, W. and Levin, R. (1989), "Innovation and market structure", in Schmalensee, R. and Willig R.D. (Ed.), The handbook of industrial organization, Elsevier Science, New York, Vol. 2, pp. 1059-107.

Cohen, W. and Levinthal, D. (1990), "Absorptive capacity: A new perspective on learning and innovation", Administrative Science Quarterly, Vol. 35, pp. 128-152.

Collins, C.J. and Smith, K.G. (2006), "Knowledge exchange and combination: the role of human resource practices in the performance of high-technology firms", Academy of Management Journal, Vol. 49, No. 3, pp. 544-560

Damanpour, F. (2010), "An integration of research findings of effects of firm size and market competition on product and process innovations", British Journal of Management, Vol. 21, No. 4, pp. 996-1010. 
Darroch, J. (2005), "Knowledge management, innovation and firm performance", Journal of Knowledge Management, Vol. 9 Iss. 3, pp.101 - 115

Delgado-Verde, M., Castro, G. M. and Navas-López, J. E., (2011), "Organizational Knowledge Assets and Innovation Capability: Evidence from Spanish Manufacturing Firms", Journal of Intellectual Capital, Vol. 12, No. 1, pp. 5-19.

Đorđević, M., Obradović, S. aAnd Lojanica, N. (2014), "Komparativna analiza razvijenosti Šumadijskog i ostalih regiona u Republici Srbiji", in Maksimović Lj. and Stanišić N. (Ed.), Stanje i perspektive ekonomskog razvoja grada Kragujevca, Ekonomski fakultet, Univerzitet u Kragujevcu, pp. 53-60.

Dost, M., Badir, Y., Ali, Z. and Tariq, A. (2016), "The impact of intellectual capital on innovation generation and adoption", Journal of Intellectual Capital, Vol. 17 Iss: 4, pp. $675-695$

Dumay, J., Rooney, J. and Marini, L. (2013), "An intellectual capital-based differentiation theory of innovation practice", Journal of Intellectual Capital, Vol. 14, Issue 4, pp. $608-633$.

Dzenopoljac, V., Janosevic, S. and Bontis, N. (2016), "Intellectual capital and financial performance in the Serbian ICT industry", Journal of Intellectual Capital, Vol 17, No. 2, pp. 373-396

Edvinsson, L. (2002), Corporate Longitude, Book House Publishing, Stockholm.

Edvinsson, L. and Malone, M. (1997), Intellectual capital: Realising your company's true value by finding its hidden brainpower, Harper Collins, New York.

Erikson, T. (2002), "Entrepreneurial capital: the emerging venture's most important asset and competitive advantage", Journal of Business Venturing, Vol. 17, pp. 275-290.

European Commission (2006), RICARDIS: Reporting Intellectual Capital to Augment Research, Development and Innovation in SMEs, European Commission: Directorate-General for Research, Brussels

Firkin, P. (2003), "Entrepreneurial Capital", in De Bruin A. and Dupuis (Ed.), Entrepreneurship: New Perspectives in a Global Age, Ashgate, Aldershot, pp. 57-75.

Fornell, C., \& Larcker, D. F. (1981). Evaluating structural equation models with unobservable and measurement errors. Journal of Marketing Research , 18 (1), 39-50.

Grujić, D., Vojnović, B. and Antonijević Simić, D. (2010), Nov pristup regionalnom razvoju, Regionalni razvoj $i$ demografski tokovi zemalja jugoistočne Evrope, Ekonomski fakultet, Univerzitet u Nišu.

Hair, J. F., Hult, G. T. M., Ringle, C. and Sarstedt, M. (2013). A Primer on Partial Least Squares Structural Equation Modeling (PLS-SE). Sage Publications, Inc.

Hamel, G. (1998), "Strategy Innovation", Executive Excellence, Vol. 15, No. 8, pp. 7-8.

Henseler, J., Ringle, C. M., \& Sinkovics, R. R. (2009). The use of partial least squares path modeling in international marketing. In R. R. Sinkovics, \& P. N. Ghauri (Eds.), Advances in International Marketing (pp. 277-319). Bingley: Emerald.

Hsu I-C. and Sabherwal R. (2012), "Relationship between Intellectual Capital and Knowledge Management: An Empirical Investigation", Decision Sciences, Vol. 43, No. 3, pp.489-524.

Hughes, M. and Morgan, R. E. (2007), "Deconstructing the relationship between entrepreneurial orientation and business performance at the embryonic stage of firm growth", Industrial Marketing Management, 36, 651-661.

Inkinen, H., Kianto, A., Vanhala, M. and Ritala, P. (2014a), "Intellectual capital and performance - Empirical findings from Finnish firms", in International Forum on 
Knowledge Assets Dynamics (IFKAD) proceedings, 11-13 June, Matera, Italy, pp. 2918-2933.

Inkinen, H. (2015) "Review of empirical research on intellectual capital and firm performance." Journal of Intellectual capital, Vol. 16, No. 3, pp. 518-565.

Inkinen, H., Vanhala, M., Ritala, P. and Kianto, A. (2014) Assessing measurement invariance of intellectual capital. $10^{\text {th }}$ EIASM Interdisciplinary Workshop on Intangibles, Intellectual Capital and Extra-Financial Information, September 18-19, Ferrara, Italy.

Janosevic, S., Dzenopoljac V. and Bontis N. (2013), "Intellectual Capital and Financial Performance in Serbia." Knowledge and Process Management, Vol. 20, No. 1, pp. 111.

Kianto, A. (2007), "What do we really mean by the dynamic dimension of intellectual capital?What do we really mean by the dynamic dimension of intellectual capital?", International Journal of Learning and Intellectual Capital, Vol. 4, No. 4, pp. 342356.

Kianto, A. (2008), "Development and validation of a survey instrument for measuring organizational renewal capability", International Journal of Technology Management, Vol. 42, No. 1, pp. 69-88.

Kianto, A. Ritala, P.,Spender, J.C. and Vanhala, M. (2014), "The interaction of intellectual capital assets and knowledge management practices in organizational value creation", Journal of Intellectual Capital, Vol. 15, No. 3, pp. 375-362.

Kianto, A., Hurmelinna-Laukkanen, P. and Ritala, P. (2010), "Intellectual capital in service- and product-oriented companies", Journal of Intellectual Capital, Vol. 11, No. 3, pp. 305-325.

Kong, E. (2010), "Innovation processes in social enterprises: an IC perspective", Journal of Intellectual Capital, Vol 11, No. 2, pp.158-178.

Kontic, LJ., Cabrilo, S. (2009), "A Strategic Model for Measuring Intellectual Capital in Serbian Industrial Enterprises", Economic Annals, Volume LIV, No. 183, pp. 89-118.

Laursen, K. (2002), "The Importance of Sectoral Differences in the Application of Complementary HRM Practices for Innovation Performance", International Journal of the Economics of Business, Vol. 9, pp. 139-156.

Leitner, K.-H. (2011), "The effect of intellectual capital on product innovativeness in SMEs“, International journal of technology management, Vol. 53, No. 1, pp 1-18.

Lepak, D.P. and Snell, S.A. (1999), "The Human Resource Architecture: Toward a Theory of Human Capital Allocation and Development", Academy of Management Review, Vol. 24, pp. 31-48.

Lerro, A., Linzalone, R. and Schiuma, G. (2014), "Managing intellectual capital dimensions for organizational value creation", Journal of Intellectual Capital, Vol. 15, No. 3, pp. 361-350.

Lumpkin G T and Dess G G (1996) Clarifying the entrepreneurial orientation construct and linking it to performance. Academy of management Review, Vol. 21, No. 1, pp. 135-172.

Maditinos, D., Šević, Z. and Tsairidis, C. (2010), "Intellectual Capital and Business Performance: An Empirical Study for the Greek Listed Companies", European Research Studies Journal, Vol. 13, No. 3, pp. 145-167. 
Maklan, S., Knox, S. and Ryals, L. (2008), "New trends in innovation and customer relationship management: a challenge for market researchers", International Journal of Market Research, Vol. 50, No. 2, pp. 221-40.

Marr, B. (2004), "Strategic management of intangible value drivers" in Coate, P. (Ed.), Handbook of Business Strategy 2005, Emerald Group Publishing Limited, Bradford, GBR, pp. 147-154.

Marr, B. and Schiuma, G. (2001), "Measuring and managing intellectual capital and knowledge assets in new economy", in Bourne M. (Ed.), Handbook of Performance Measurement, Gee, London.

Marvel, M.R. and Lumpkin, G.T. (2007), "Technology entrepreneurs' human capital and its effects on innovation radicalness", Entrepreneurship: Theory and Practice, Vol. 31, No. 6, pp. 807-28.

Mathuramaytha, C. (2012) "The Impacts of Intellectual Capital on Innovative Capability: Building the Sustain Competitive Advantage on a Resource-Based Perspective of Thailand Industrials", International Business Management, Vol. 6, No. 4, pp.451-457.

Mayer, R. C., Davis, J. H. and Schoorman, F. D. (1995), "An integrative model of organizational trust". Academy of Management Review, Vol. 20, No. 3, pp. 709-734.

Mention, A. and Bontis, N. (2013), "Intellectual capital and performance within the banking sector of Luxembourg and Belgium", Journal of Intellectual Capital, Vol. 14 , No. 2, pp. $286-309$.

Meritum (2002), Proyecto Meritum: Guidelines for Managing and Reporting Intangibles, Meritum, Madrid.

Michael, S. and Pearce, J. (2009), "The need for innovation as a rationale for government involvement in entrepreneurship", Entrepreneurship \& Regional Development, Vol. 21, No. 3, May 2009, pp. 285-302.

Mijačić, D. and Paunović, B. (2011), "Regional Disparities in Serbia", Ekonomika preduzeća, November -December, pp. 379-389.

Miller, D. and Friesen, P. (1982), "Innovation in conservative and entrepreneurial firms: Two models of strategic momentum", Strategic Management Journal, Vol. 3, No. 1, pp. 1-25.

Nahapiet, J. and Ghoshal, S. (1998), "Social capital, intellectual capital, and the organizational advantage", Academy of Management Review, Vol. 23 No. 2, pp. 24266.

Nonaka, I. and Takeuchi, H. (1995), The Knowledge Creating Company: How Japanese Companies Create the Dynamics of Innovation. New York: Oxford University Press.

Peng, T. A., Pike S. and Roos, G. (2007), "Intellectual capital and performance indicators: Taiwanese healthcare sector", Journal of Intellectual Capital, Vol. 8, No.3, pp. 538-556.

Rass, M., Dumbach, M., Danzinger, F., Bullinger A.C. and Moeslein, K.M. (2013), "Open Innovation and Firm Performance: The Mediating Role of Social Capital", Creativity and Innovation Management, Vol. 22, No.2, pp. 177-194.

Roos, J., Roos, G., Dragonetti, N.C. and Edvinsson, L. (1998), Intellectual Capital: Navigating in the New Business Landscape, New York University Press, New York.

Šabić, D., Vujadinović S., Milinčić M., Golić R., Stojković S., Joksimović M., Dejan Filipović D. and Šećerov, V. (2012), "The Impact of FDI on the Transitional 
Economy in Serbia - Changes and Challenges", Acta Polytechnica Hungarica, Vol. 9, No. 3, pp. 65-84.

Santos-Rodrigues, H., Faria, J., Cranfield, D. and Morais, C. (2013), "Intellectual Capital and Innovation: A Case Study of a Public Healthcare organisation in Europe", Electronic Journal of Knowledge Management, Vol. 11, Issue 4, pp.361-372.

Santos-Rodrigues, H., Figueroa, P., and Fernandez-Jardon, C. (2011), "The main intellectual capital components that are relevant to the product, process and management firm innovativeness", International Journal of Transitions and Innovation Systems, Vol. 1, No. 3, pp. 271-301.

Scherer, F.M. (1999), New perspectives on economic growth and technological innovation, Brookings Institution, Washington, DC.

Stewart, T.A. (1997), Intellectual Capital: The New Wealth of Organizations, Doubleday, New York.

Subramaniam, M. and Youndt, M. (2005), "The influence of intellectual capital on the types of innovative capabilities", Academy of Management Journal, 2005, Vol. 48, No. 3, pp. 450-463.

Sumita, T. (2008), "Intellectual assets based management for innovation Lessons from experiences in Japan", Journal of Intellectual Capital, Vol. 9 No. 2, pp. 206-227.

Sveiby, K.E. (1997), The New Organizational Wealth: Managing and Measuring Knowledge-based Assets, Berrett-Koehlen, New York.

Sveiby, K.-E. (2012), "Innovation and the global financial crisis: systemic consequences of incompetence", in Sveiby, K.-E., Gripenberg, P. and Segercrantz, B. (Eds), Challenging the Innovation Paradigm, Routledge, New York, NY, pp. 113-142.

Sveiby, K.-E., Gripenberg, P. and Segercrantz, B. (Eds) (2012), Challenging the Innovation Paradigm. Routledge Studies in Technology, Work and Organizations, Routledge, New York, NY and London.

Sveiby, K.-E., Gripenberg, P., Segercrantz, B., Eriksson, A. and Aminoff, A. (2009), "Unintended and undesirable consequences of innovation", paper presented at the XX ISPIM Conference, The Future of Innovation, Vienna, 21-24 June.

Takayuki, S. (2008), "Intellectual assets based management for innovation: Lessons from experiences in Japan", Journal of intellectual capital, Vol 9, No.2, pp.206-277.

Teece, D.J. (2007), "Explicating dynamic capabilities: the nature and microfoundations of (sustainable) enterprise performance", Strategic Management Journal, Vol. 28 No. 13, pp. 1319-1350.

Tidd, J. (2001), "Innovation management in context: environment, organization and performance", International Journal of Management Reviews, Vol. 3, No. 3, pp. 169183.

Tidd, J. And Bessant, J. (2009), Managing innovation: integrating technological, market, and organizational change, John Wiley \& Sons Ltd

Tovstiga, G. and Tulugurova, E., (2007), "Intellectual Capital Practices and Performance in Russian Enterprises", Journal of Intellectual Capital, Vol. 8, No. 4, pp. 695-707.

Tseng, C. Y. and Goo, Y. J. J. (2005), "Intellectual capital and corporate value in an emerging economy: empirical study of Taiwanese manufacturers", $R \& D$ Management, Vol. 35, No. 2, pp. 187-201.

Van de Ven, A.H. (1986), "Central Problems in the Management of Innovation", Management Science, Vol. 32, pp. 590-607. 
Veselinović, P. (2014), "The reform of the public sector as the key determinant of the transition economy of the Republic of Serbia", Economic Horizons, Vol 16, No. 2 pp. 137-155.

Wang, W.Y. and Chingfu, C. (2005), "Intellectual Capital and performance in causal models: Evidence from the information technology industry in Taiwan", Journal of Intellectual Capital, Vol 6, No. 2, pp.222-236.

Weerawardena, J. (2003), "Exploring the role of market learning capability in competitive strategy", European Journal of Marketing, Vol. 37, No. 3/4, pp. 407-429.

Weggeman, M. (1997), Knowledge management; design and management of knowledge intensive organizations. Schiedam: Scriptum.

Wolfe, R.A. 1994. Organisational innovation: Review, critique and suggested research directions. Journal of Management Studies, May, 31(3): 405-425.

Wu, S.H., Lin, L.Y. and Hsu, M.Y. (2007), "Intellectual capital, dynamic capabilities and innovative performance of organizations", International Journal of Technology Management, Vol. 39, No. 3-4, pp. 279-96.

Youndt, M., Subramanian, M., and Snell, S. (2004), "Intellectual Capital Profiles: An Examination of Investments and Returns", Journal of Management Studies, Vol. 42, No. 2, pp.335-361.

Zahra, S. (1996), "Governance, ownership, and corporate entrepreneurship: The moderating impact of industry technological opportunities", Academy of Management Journal, Vol. 39, No. 6, pp. 1713-1735.

\section{Appendix 1 GOES HERE}


Table I. Regional diversity of the sample

\begin{tabular}{|c|c|c|c|}
\hline & Region & $\begin{array}{l}\text { Number of } \\
\text { companies }\end{array}$ & $\begin{array}{l}\% \text { of the } \\
\text { sample }\end{array}$ \\
\hline \multirow{2}{*}{ Serbia-North } & Belgrade & 42 & $42 \%$ \\
\hline & Vojvodina & 33 & $33 \%$ \\
\hline \multirow{2}{*}{ Serbia-South } & Šumadija and Western Serbia & 15 & $15 \%$ \\
\hline & Southern and Eastern Serbia & 10 & $10 \%$ \\
\hline & & 100 & $100 \%$ \\
\hline
\end{tabular}

(c) Emerald Publishing Limited

This is a pre-print of a paper and is subject to change before publication. This pre-print is made available with the understanding that it will not be reproduced or stored in a retrieval system without the permission of Emerald Publishing Limited. 
Table II. The structure of the sample according to the industries

\begin{tabular}{|c|c|c|}
\hline Industry & $\begin{array}{l}\text { Number of } \\
\text { companies }\end{array}$ & $\begin{array}{l}\% \text { of the } \\
\text { sample }\end{array}$ \\
\hline Manufacturing & 49 & $49 \%$ \\
\hline Manufacture of food products and beverages & 26 & $26 \%$ \\
\hline Manufacture of chemicals (excluding pharmaceuticals) & 5 & $5 \%$ \\
\hline Manufacture of wood and product of wood & 4 & $4 \%$ \\
\hline Metallurgy & 3 & $3 \%$ \\
\hline Manufacture of consumer goods & 2 & $2 \%$ \\
\hline Manufacture of pharmaceuticals products & 2 & $2 \%$ \\
\hline Manufacture of paper and paper products & 2 & $2 \%$ \\
\hline Manufacturer of building materials & 2 & $2 \%$ \\
\hline Car and car equipment manufacturer & 2 & $2 \%$ \\
\hline Manufacture of textile & 1 & $1 \%$ \\
\hline Information and communication & 12 & $12 \%$ \\
\hline Administrative and support service activities & 8 & $8 \%$ \\
\hline Financial and insurance activities & 8 & $8 \%$ \\
\hline Construction & 6 & $6 \%$ \\
\hline Wholesale and retail trade & 5 & $5 \%$ \\
\hline Agriculture, forestry and fishery & 3 & $3 \%$ \\
\hline Electricity, gas, steam and air conditioning supply & 3 & $3 \%$ \\
\hline Professional, scientific and technical activities & 2 & $2 \%$ \\
\hline Transportation and storage & 2 & $2 \%$ \\
\hline Mining and quarrying & 1 & $1 \%$ \\
\hline \multirow[t]{2}{*}{ Accommodation and food service activities } & 1 & $1 \%$ \\
\hline & 100 & $100 \%$ \\
\hline
\end{tabular}


Table III. Sample structure according to the respondents' position

\begin{tabular}{|l||c||c||}
\hline Position of respondent & Number & $\%$ of the sample \\
\hline \hline Managing Director & 7 & $7 \%$ \\
\hline HR Manager/Director & 34 & $34 \%$ \\
\hline Other Manager/Director & 47 & $47 \%$ \\
\hline Expert & 9 & $9 \%$ \\
\hline Other (Advisors and Board Members) & 3 & $3 \%$ \\
\hline
\end{tabular}


Table IV. Correlation matrix

\begin{tabular}{|c|c|c|c|c|c|c|c|c|}
\hline & Mean & SD & 1. & 2. & 3. & 4. & 5. & 6. \\
\hline 1.Innovation performance & 2.94 & 0.59 & & & & & & \\
\hline 2.Internal relational capital & 3.94 & 0.81 & $0.568^{*}$ & & & & & \\
\hline 3.External relational capital & 3.96 & 0.65 & $0.579 *$ & $0.640^{*}$ & & & & \\
\hline 4. Structural capital & 3.97 & 0.75 & $0.614^{*}$ & $0.513 *$ & $0.555^{*}$ & & & \\
\hline 5. Human capital & 3.69 & 0.81 & $0.536^{*}$ & $0.734 *$ & $0.692 *$ & $0.470^{*}$ & & \\
\hline 6. Renewal capital & 3.63 & 0.89 & $0.643^{*}$ & $0.556^{*}$ & $0.683^{*}$ & $0.644^{*}$ & $0.752 *$ & \\
\hline 7. Entrepreneurial capital & 3.24 & 0.83 & $0.607^{*}$ & $0.604 *$ & $0.617^{*}$ & $0.606^{*}$ & $0.651 *$ & $0.768 *$ \\
\hline
\end{tabular}

Notes: $* *$ Correlation is significant at the 0.01 level 
Table V. Internal consistency and convergent validity

\begin{tabular}{lll}
\hline & CR & AVE \\
\hline 1.Innovation performance & 0.92 & 0.70 \\
2.Internal relational capital & 0.91 & 0.84 \\
3.External relational capital & 0.91 & 0.84 \\
4. Structural capital & 0.90 & 0.70 \\
5. Human capital & 0.90 & 0.82 \\
6. Renewal capital & 0.94 & 0.80 \\
7. Entrepreneurial capital & 0.92 & 0.67 \\
\hline
\end{tabular}

(c) Emerald Publishing Limited

This is a pre-print of a paper and is subject to change before publication. This pre-print is made available with the understanding that it will not be reproduced or stored in a retrieval system without the permission of Emerald Publishing Limited. 
Table VI. Discriminant validity of the research model

\begin{tabular}{|c|c|c|c|c|c|c|c|}
\hline & 1. & 2. & 3. & 4. & 5. & 6. & 7. \\
\hline 1.Innovation performance & 0.696 & & & & & & \\
\hline 2.Internal relational capital & 0.322 & 0.840 & & & & & \\
\hline 3.External relational capital & 0.335 & 0.410 & 0.840 & & & & \\
\hline 4. Structural capital & 0.378 & 0.263 & 0.308 & 0.700 & & & \\
\hline 5. Human capital & 0.287 & 0.539 & 0.486 & 0.221 & 0.816 & & \\
\hline 6. Renewal capital & 0.413 & 0.309 & 0.466 & 0.415 & 0.566 & 0.797 & \\
\hline 7. Entrepreneurial capital & 0.368 & 0.371 & 0.380 & 0.367 & 0.424 & 0.590 & 0.667 \\
\hline
\end{tabular}

(C) Emerald Publishing Limited

This is a pre-print of a paper and is subject to change before publication. This pre-print is made available with the understanding that it will not be reproduced or stored in a retrieval system without the permission of Emerald Publishing Limited. 
Table VII. Model test results

\begin{tabular}{|c|c|c|c|c|c|c|}
\hline & & & VIF & Path coefficient & T statistics & p-value \\
\hline H1: Internal relational capital & $\rightarrow$ & & 2.730 & 0.228 & 2.401 & 0.017 \\
\hline H2: External relational capital & $\rightarrow$ & & 2.391 & 0.145 & 1.334 & 0.183 \\
\hline H3: Structural capital & $\rightarrow$ & Innovation & 2.002 & 0.222 & 1.961 & 0.050 \\
\hline H4: Human capital & $\rightarrow$ & performance & 3.903 & -0.155 & 1.003 & 0.316 \\
\hline H5: Renewal capital & $\rightarrow$ & & 4.198 & 0.312 & 2.236 & 0.026 \\
\hline H6: Entrepreneurial capital & $\rightarrow$ & & 2.818 & 0.114 & 0.958 & 0.339 \\
\hline
\end{tabular}

(c) Emerald Publishing Limited

This is a pre-print of a paper and is subject to change before publication. This pre-print is made available with the understanding that it will not be reproduced or stored in a retrieval system without the permission of Emerald Publishing Limited. 


\section{Appendix 1}

Factor loadings of measurement items

\begin{tabular}{|c|c|c|c|}
\hline Construct & Item & $\begin{array}{c}\text { Factor } \\
\text { loadings }\end{array}$ & $P$ \\
\hline \multirow{6}{*}{ 1.Innovation performance } & $\begin{array}{l}\text { Compared to its competitors, how successfully has your } \\
\text { company managed to create innovations/new operating } \\
\text { methods in the following areas over the past year? }\end{array}$ & & 0.000 \\
\hline & Products and services for customers & 0.810 & 0.000 \\
\hline & Production methods and processes & 0.850 & 0.000 \\
\hline & Management practices & 0.850 & 0.000 \\
\hline & Marketing practices & 0.809 & 0.000 \\
\hline & Business models & 0.853 & 0.000 \\
\hline \multirow{2}{*}{ 2. Internal relational capital } & $\begin{array}{l}\text { Different units and functions within our company - such as } \\
\text { R\&D, marketing and production - understand each other well. }\end{array}$ & 0.920 & 0.000 \\
\hline & Internal cooperation in our company runs smoothly & 0.913 & 0.000 \\
\hline \multirow{2}{*}{$\begin{array}{l}\text { 3. External relational } \\
\text { capital }\end{array}$} & $\begin{array}{l}\text { Our company and its external stakeholders - such as customers, } \\
\text { suppliers and partners - understand each other well. }\end{array}$ & 0.938 & 0.000 \\
\hline & $\begin{array}{l}\text { Cooperation between our company and its external stakeholders } \\
\text { runs smoothly. }\end{array}$ & 0.894 & 0.000 \\
\hline \multirow{4}{*}{ 4. Structural capital } & $\begin{array}{l}\text { Our company has efficient and relevant information systems to } \\
\text { support business operations. }\end{array}$ & 0.815 & 0.000 \\
\hline & $\begin{array}{l}\text { Our company has tools and facilities to support cooperation } \\
\text { between employees. }\end{array}$ & 0.843 & 0.000 \\
\hline & $\begin{array}{l}\text { Our company has a great deal of useful knowledge in } \\
\text { documents and databases. }\end{array}$ & 0.868 & 0.000 \\
\hline & Existing documents and solutions are easily accessible. & 0.820 & 0.000 \\
\hline \multirow{2}{*}{ 5. Human capital } & Our employees are highly motivated in their work. & 0.932 & 0.000 \\
\hline & Our employees have a high level of expertise. & 0.874 & 0.000 \\
\hline \multirow{4}{*}{ 6. Renewal capital } & $\begin{array}{l}\text { Our company has acquired a great deal of new and important } \\
\text { information }\end{array}$ & 0.922 & 0.000 \\
\hline & $\begin{array}{l}\text { Our employees have acquired a great deal of important skills } \\
\text { and abilities }\end{array}$ & 0.899 & 0.000 \\
\hline & Our company can be described as a learning organization. & 0.881 & 0.000 \\
\hline & $\begin{array}{l}\text { The operations of our company can be described as creative and } \\
\text { inventive. }\end{array}$ & 0.868 & 0.000 \\
\hline \multirow{6}{*}{ 7. Entrepreneurial capital } & $\begin{array}{l}\text { Risk-taking is regarded as a positive personal quality in our } \\
\text { company. }\end{array}$ & 0.744 & 0.000 \\
\hline & Our employees take deliberate risks related to new ideas. & 0.810 & 0.000 \\
\hline & $\begin{array}{l}\text { Our employees are excellent at identifying new business } \\
\text { opportunities. }\end{array}$ & 0.844 & 0.000 \\
\hline & Our employees show initiative. & 0.816 & 0.000 \\
\hline & $\begin{array}{l}\text { The operations of our company are defined by independence } \\
\text { and freedom in performing duties. }\end{array}$ & 0.857 & 0.000 \\
\hline & $\begin{array}{l}\text { Our employees have the courage to make bold and difficult } \\
\text { decisions. }\end{array}$ & 0.825 & 0.000 \\
\hline
\end{tabular}

Production methods and processes

.000

0.000

each other well.

0.000

Cooperation between our company and its external stakeholders

Our company has efficient and relevant information systems to

0.000

(1)

Our company has a great deal of useful knowledge in

Existing documents and solutions are easily accessible.

.000 